\title{
Comparison of thermochemical treatment of sewage sludge ash with sodium sulphate in laboratory-scale and pilot-scale experiments
}

\author{
H. Herzel ${ }^{1}$ D . J. Stemann ${ }^{2} \cdot$ S. Simon ${ }^{1}$ (D) . C. Adam ${ }^{1}$ (D)
}

Received: 21 October 2020 / Revised: 18 February 2021 / Accepted: 1 March 2021 / Published online: 26 March 2021

(c) The Author(s) 2021

\begin{abstract}
There is an ongoing debate on European scale concerning the criticality of phosphorus. In Switzerland and Germany, phosphorus recovery from phosphorus-rich waste streams will become obligatory. Sewage sludge ash is rich in phosphorus and may become an important secondary feedstock. Thermochemical treatment of sewage sludge ash with sodium sulphate under reducing conditions was shown to remove heavy metals from the solid product and produce the fully plant available crystalline phase $\mathrm{CaNaPO}_{4}$. Pilot-scale experiments in a rotary kiln were carried out at temperatures between 750 and $1000{ }^{\circ} \mathrm{C}$ and were compared to laboratory-scale experiments with crucibles. Process upscaling was successfully demonstrated but a series of differences were noticed: In comparison to laboratory-scale, solubility of phosphorus in samples from pilot-scale experiments was lower at all chosen treatment temperatures because of shorter retention time and incomplete decomposition of sodium sulphate. X-ray diffraction analysis revealed remaining phase fractions of whitlockite $\left(\mathrm{Ca}_{3-\mathrm{x}}(\mathrm{Mg}, \mathrm{Fe})_{\mathrm{x}}\left(\mathrm{PO}_{4}\right)_{2}\right)$ and sodium sulphate from the starting materials in products and thus indicated incomplete reaction. In contrast to the results of laboratory-scale experiments, the crystalline phase $\mathrm{CaNaPO}_{4}$ was clearly absent in the products from the rotary kiln but instead a $\mathrm{Mg}$-bearing phase $(\mathrm{Ca}, \mathrm{Mg}) \mathrm{NaPO}_{4}$ was formed. Laboratory-scale experiments confirmed $(\mathrm{Ca}, \mathrm{Mg}) \mathrm{NaPO}_{4}$ is an intermediate phase between whitlockite and $\mathrm{CaNaPO}_{4}$. However, both crystalline phases are characterized by high plant availability. It was shown that heavy metal removal increased at higher temperatures whereas solubility and thus plant availability of phosphorus already reached its maxima at temperatures of $950{ }^{\circ} \mathrm{C}$ in pilot-scale and $875{ }^{\circ} \mathrm{C}$ in laboratory-scale experiments.
\end{abstract}

Keywords Crystalline phase identification $\cdot$ Heavy metal removal $\cdot$ Phosphorus availability $\cdot$ Process upscaling $\cdot$ Recovery $\cdot$ Rhenanite

\section{Introduction}

Phosphorus together with nitrogen and potassium is the most important fertilizer ingredient. However, conventional phosphorus reserves that are low in impurities and easily accessible will likely become scarce in the future (Gilbert 2009). Moreover, Europe has a phosphorus import dependency of $92 \%$ (EC 2013). Given the criticality of phosphorus,

Editorial responsibility: Maryam Shabani.

$\triangle$ H. Herzel

herzelhannes@gmail.com

1 Bundesanstalt für Materialforschung und -Prüfung (BAM), Unter den Eichen 87, 12205 Berlin, Germany

2 Technical Services Water \& Energy, Omya International AG, Baslerstrasse 42, CH-4665 Oftringen, Switzerland the European Commission has included phosphate rock to its list of 20 Critical Raw Materials in 2014 (EC 2014; EC 2017). Recovery of phosphorus from waste streams is regarded as an important measure to reduce the dependency on phosphorus imports. In Switzerland, phosphorus recovery will become mandatory after a grace period in 2026 (VVEA 2016) and in Germany in 2029 (AbfKlärV 2017). Phosphorus needs to be removed from wastewater in order to avoid eutrophication in receiving water bodies. In Europe, sewage sludge is the most important phosphorus bearing waste stream. It makes up a total of $233 \mathrm{t}$ out of $1217 \mathrm{t}$ of total European phosphorus losses per year (van Dijk et al. 2016). Mono-incineration of sewage sludge destroys organic pollutants and produces an ash with high phosphorus content. Sewage sludge ash is therefore a promising starting material for phosphorus recovery but cannot be directly used as a fertilizer: (1) Incineration converts phosphorus 
mainly into the crystalline mineral phase whitlockite type $\mathrm{Ca}_{3-\mathrm{x}}(\mathrm{Mg}, \mathrm{Fe})_{\mathrm{x}}\left(\mathrm{PO}_{4}\right)_{2}$ (Peplinski et al. 2009). Whitlockite is poorly plant available (Nanzer et al. 2014). (2) SSA may contain elevated mass fractions of heavy metals (Krüger et al. 2014). Thus, post-treatment is necessary in order to increase plant availability and to remove heavy metals.

A promising method is thermochemical treatment together with the additive sodium sulphate $\left(\mathrm{Na}_{2} \mathrm{SO}_{4}\right)$ in a reducing atmosphere (Herzel et al. 2016; Stemann et al. 2015). This way whitlockite is converted to the crystalline phase $\alpha-\mathrm{CaNaPO}_{4}$. As the high-temperature phase is not stable under the investigated conditions, the low-temperature phase $\beta$-CaNaPO 4 (Herzel et al. 2020; Orlov et al. 2019) is identified in the product of thermochemical treatment after cooling (Stemann et al. 2015). This phase, also termed Rhenanite, is well known for its good plant availability. It was named after the Rhenania process (Werner 1967), a thermochemical treatment process for fertilizer production from rock phosphate. The produced $\mathrm{CaNaPO}_{4}$-phase can incorporate other compounds, such as $\mathrm{Ca}_{2} \mathrm{SiO}_{4}$ (Gunawardane and Glasser 1979; Widmer et al. 2015) or Ca is displaced by Mg (Alkemper and Fuess 1998) but there is no indication that the impurities have a significant influence on the plant availability of phosphorus. $\mathrm{CaNaPO}_{4}$ is poorly water soluble but it is well soluble in both alkaline and neutral ammonium citrate (Kratz et al. 2019). Solubility of phosphorus in neutral ammonium citrate has to be declared according to the proposed Swiss regulation on mineral recycling fertilizers (Zimmermann 2017) and is an excellent indicator for plant availability of phosphorus (Kratz et al. 2019; Severin et al. 2014). Extracted phosphorus in neutral ammonium citrate $\left(\mathrm{P}_{\mathrm{NAC}}\right)$ is given as a fraction $\left(\mathrm{P}_{\mathrm{NAC}, \mathrm{rel}}\right)$ of the total $\mathrm{P}$-content.

In sewage sludge ashes, heavy metals are most probably present in the form of oxides. In a reducing atmosphere, heavy metal oxides may be reduced to their metallic form or react with sulphuric compounds to volatile heavy metal sulphides such as $\mathrm{PbS}$. Due to the higher vapour pressures of those metal species in comparison to the respective oxides, heavy metals such as $\mathrm{Hg}, \mathrm{Cd}$ and $\mathrm{Pb}$ as well as the element As partly evaporate or sublimate at comparably low temperatures (Vogel et al. 2016). Heavy metals can thus be removed from the fertilizer via the gas flow and can be separated in concentrated form in conventional gas cleaning systems.

Sufficiently high temperatures are required to form the desired crystalline phases and to remove considerable quantities of heavy metals. However, apart from an increasing energy demand, high temperatures also increase material adhesion and thus the risk of material build-up and clogging. The aim of the present study is to report on a process upscaling from laboratory-scale experiments in crucibles to pilot-scale experiments in an indirectly electrically heated rotary kiln. These experiments compare the product quality parameters phosphorus solubility, crystalline phase formation and heavy metal removal of the thermochemical products from laboratory- and pilot-scale over a temperature range of $750-1000{ }^{\circ} \mathrm{C}$. It was intended to identify sufficient minimal treatment temperatures that guarantee high product quality at low energy consumption.

The pilot-scale and laboratory-scale experiments were conducted in the years 2015 and 2017, respectively. Chemical analysis and X-ray diffraction analysis were completed in 2020. All works were performed essentially at the Federal Institute for Materials Research and Testing (Berlin, Germany).

\section{Materials and methods}

\section{Materials}

Sewage sludge ash from the incineration facility of the municipal wastewater treatment plant in Berlin-Ruhleben, Germany, was used. Dried sewage sludge was acquired from Wassmannsdorf wastewater treatment plant (near Berlin, Germany). Sewage sludge was characterized by a water content of $8 \%$ and an ash content of $29 \%$. Elemental compositions of the raw materials are displayed in Table 1. Due to the pilot character of the experiments, anhydrous sodium sulphate from a potential supplier for an industrial scale process was acquired. Anhydrous sodium sulphate of high purity ( $>99.9 \%$ ) is a by-product from rayon production. Rayon grade sodium sulphate was acquired from Cordenka, Obernburg, Germany. With a production volume of sodium sulphate of $40 \mathrm{kt} / \mathrm{a}$, it may become a potential supplier of sodium sulphate for an industrial scale phosphorus recovery plant in Germany. For laboratory-scale experiments, sodium sulphate anhydrous fine powder analytical reagent grade from Fisher Scientific, Loughborough, UK was used.

\section{Calcination experiments}

\section{Laboratory-scale experiments}

$10.00 \mathrm{~g}$ of sewage sludge ash was mixed with $2.00 \mathrm{~g}$ of dry sludge and $4.00 \mathrm{~g}$ of sodium sulphate. The starting materials were mixed for $30 \mathrm{~min}$ in an overhead mixer at $40 \mathrm{~min}^{-1}$ and were subsequently transferred to crucibles with a volume of $85 \mathrm{~mL}$. Due to the high ferric content and the reducing conditions, experiments were not performed in Pt but in corundum $\left(\mathrm{Al}_{2} \mathrm{O}_{3}\right)$ crucibles. The material mixtures were calcined in a preheated muffle furnace at different temperatures from $750{ }^{\circ} \mathrm{C}$ up to $1000{ }^{\circ} \mathrm{C}$ for $30 \mathrm{~min}$. After calcination, the crucibles were removed from the furnace and could cool at ambient conditions. During calcination and cooling, the crucibles were covered with a corundum lid in order to maintain reducing conditions. The crucible filled with the 
Table 1 Mass fractions of sewage sludge ash, sewage sludge and samples from laboratory-scale and pilot-scale experiments (L $1000=$ laboratory-scale experiment at $1000{ }^{\circ} \mathrm{C}, \quad \mathrm{P} \quad 750-\mathrm{P}$
$1000=$ pilot-scale experiments at $750-1000{ }^{\circ} \mathrm{C},{ }^{1}$ mass fraction of phosphorus in sample which is soluble in neutral ammonium citrate $\left(\mathrm{P}_{\mathrm{NAC}}\right), \mathrm{SD}=$ standard deviation, in triplicates)

\begin{tabular}{|c|c|c|c|c|c|c|c|c|c|c|c|c|c|c|c|c|c|c|}
\hline & \multicolumn{2}{|l|}{ Ash } & \multicolumn{2}{|c|}{$\begin{array}{l}\text { Sewage } \\
\text { sludge }\end{array}$} & \multicolumn{2}{|l|}{ L 1000} & \multicolumn{2}{|l|}{ P 750} & \multicolumn{2}{|l|}{ P 800} & \multicolumn{2}{|l|}{ P 850} & \multicolumn{2}{|l|}{ P 900} & \multicolumn{2}{|l|}{ P 950} & \multicolumn{2}{|l|}{ P 1000} \\
\hline & mean & SD & mean & SD & mean & SD & Mean & SD & mean & SD & mean & SD & mean & SD & mean & SD & mean & SD \\
\hline \multicolumn{19}{|l|}{ wt $\%$} \\
\hline $\mathrm{Al}$ & 2.97 & 0.08 & 0.76 & 0.00 & 2.70 & 0.02 & 2.10 & 0.01 & 2.23 & 0.03 & 2.20 & 0.02 & 2.13 & 0.03 & 2.11 & 0.00 & 2.21 & 0.07 \\
\hline $\mathrm{Ca}$ & 12.37 & 0.08 & 3.42 & 0.02 & 11.10 & 0.08 & 9.50 & 0.04 & 10.24 & 0.09 & 9.86 & 0.08 & 9.65 & 0.03 & 9.66 & 0.02 & 10.22 & 0.20 \\
\hline $\mathrm{Fe}$ & 13.88 & 0.39 & 1.03 & 0.01 & 12.88 & 0.08 & 12.10 & 0.11 & 13.30 & 0.08 & 13.07 & 0.01 & 12.48 & 0.03 & 12.50 & 0.09 & 13.08 & 0.24 \\
\hline K & 1.10 & 0.07 & 0.35 & 0.05 & 0.93 & 0.04 & 1.06 & 0.02 & 1.06 & 0.03 & 1.03 & 0.04 & 1.02 & 0.03 & 0.98 & 0.05 & 1.02 & 0.03 \\
\hline $\mathrm{Mg}$ & 1.32 & 0.01 & 1.93 & 0.01 & 1.49 & 0.01 & 1.27 & 0.01 & 1.33 & 0.02 & 1.31 & 0.01 & 1.32 & 0.00 & 1.28 & 0.01 & 1.36 & 0.01 \\
\hline $\mathrm{Na}$ & 1.48 & 0.17 & 0.16 & 0.00 & 11.12 & 0.02 & 8.33 & 0.02 & 7.38 & 0.07 & 8.51 & 0.12 & 9.39 & 0.06 & 9.92 & 0.03 & 9.27 & 0.12 \\
\hline $\mathrm{P}$ & 11.20 & 0.16 & 3.84 & 0.02 & 7.46 & 0.09 & 7.74 & 0.25 & 8.33 & 0.41 & 8.16 & 0.50 & 7.86 & 0.48 & 7.81 & 0.54 & 8.06 & 0.58 \\
\hline $\mathrm{P}_{\mathrm{NAC}}{ }^{1}$ & 2.34 & 0.05 & 1.22 & 0.01 & 6.64 & 0.34 & 1.88 & 0.11 & 2.52 & 0.11 & 4.60 & 0.29 & 4.94 & 0.29 & 5.61 & 0.25 & 5.74 & 0.26 \\
\hline S & 0.89 & 0.02 & 1.29 & 0.01 & 4.94 & 0.09 & 4.70 & 0.03 & 3.18 & 0.01 & 2.93 & 0.00 & 3.48 & 0.01 & 3.79 & 0.05 & 2.84 & 0.03 \\
\hline $\mathrm{Si}$ & 8.56 & 1.50 & 2.25 & 0.02 & 6.94 & 0.46 & 7.49 & 0.50 & 7.28 & 0.22 & 7.98 & 0.50 & 8.64 & 1.12 & 7.59 & 0.01 & 7.08 & 0.15 \\
\hline \multicolumn{19}{|l|}{$\mathrm{mg} / \mathrm{kg}$} \\
\hline As & 23.4 & 1.0 & 12.0 & 1.6 & 17.5 & 1.8 & 18.8 & 2.3 & 19.7 & 3.5 & 17.2 & 1.8 & 15.3 & 1.5 & 15.0 & 1.3 & 18.8 & 2.3 \\
\hline $\mathrm{Cd}$ & 2.16 & 0.06 & 0.86 & 0.03 & 1.15 & 0.15 & 1.55 & 0.05 & 1.59 & 0.10 & 1.39 & 0.04 & 1.39 & 0.01 & 1.27 & 0.04 & 0.91 & 0.02 \\
\hline $\mathrm{Cu}$ & 2700 & 21 & 889 & 4 & 2380 & 32 & 1940 & 18 & 2120 & 13 & 2050 & 4 & 2030 & 12 & 2010 & 24 & 2090 & 9 \\
\hline $\mathrm{Pb}$ & 135 & 11.0 & 32.5 & 0.5 & 129 & 3.5 & 1.7 & 74.7 & 3.4 & 57.5 & 5.4 & 59.6 & 1.3 & 71.9 & 0.5 & 63.2 & 0.8 & 1.7 \\
\hline $\mathrm{Zn}$ & 2990 & 36 & 957 & 5 & 2960 & 10 & 2620 & 1 & 2800 & 20 & 2760 & 18 & 2630 & 4 & 2590 & 19 & 2670 & 20 \\
\hline
\end{tabular}

sample was weighed before and after each calcination. The sample was removed and pulverized in a vibrating cup mill made of tungsten carbide (Pulverisette, Fritsch).

\section{Pilot-scale experiments}

Calcination experiments were carried out in a bench scale rotary kiln (TL 1100, Thermal technology GmbH, see Fig. 1 for a visualization of the experimental set-up). The kiln consists of a temperature resistant nickel base alloy $(65 \% \mathrm{Ni}$, 25\% Cr) tube (length: $2000 \mathrm{~mm}$, inner diameter: $200 \mathrm{~mm}$ ) that rotates in an oven heated by electric heating elements. The kiln was operated at a co-current nitrogen gas flow of $600 \mathrm{~L} / \mathrm{h}$. The outlet of the kiln was partly covered by a variable metal plate to control the amount of air entering the kiln at the outlet. The reason for this construction was to provide both a reducing atmosphere in the kiln for heavy metal reduction and an oxidizing atmosphere only at the kiln outlet for partly oxidation of sulphides in the solid product.

Sample preparation consisted of mixing of $5000 \mathrm{~g}$ of sewage sludge ash, $2000 \mathrm{~g}$ of sodium sulphate and $1000 \mathrm{~g}$ of dried sewage sludge with a screw mixer. The samples were thereafter filled into the closed feeding container. The kiln was heated to the desired temperature, and the nitrogen gas flow was started. Thereafter the automatic feeding system was started. Feeding of the input stream into the kiln lasted $90 \mathrm{~min}$ at about $5.4 \mathrm{~kg} / \mathrm{h}$. All material leaving the kiln was collected and weighed.
Fig. 1 Schematic of the rotary kiln and the experimental set-up

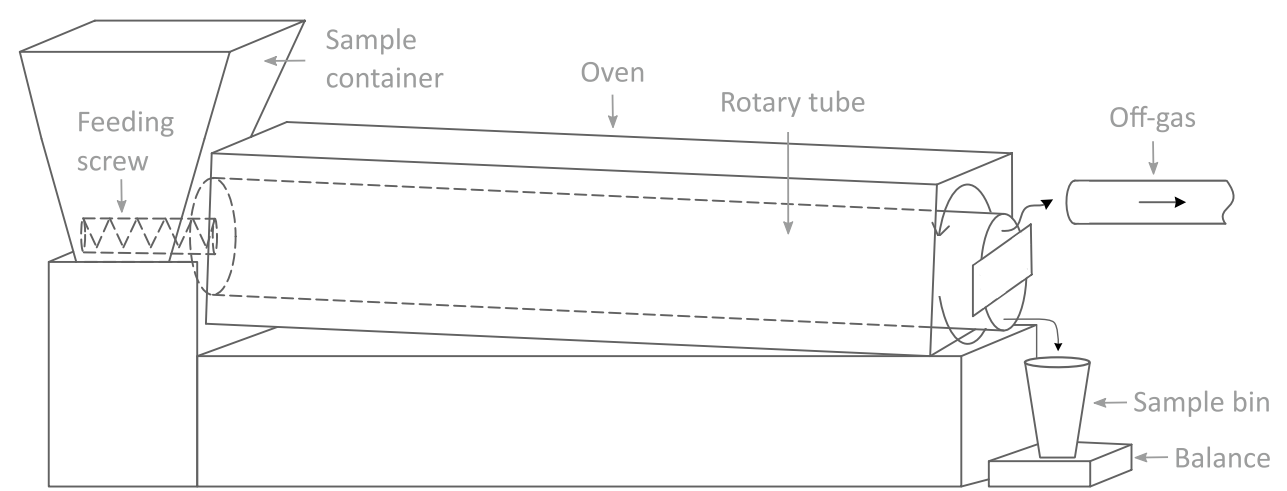


A temperature profile in the oven was periodically recorded by a manually held thermocouple of $3 \mathrm{~m}$ length (Type K, electronic sensor, Heilbronn, Germany). Figure S1 displays the temperature profile in the kiln. It can be noted that the maximal temperature was reached at the section in the oven from 1000 to $1400 \mathrm{~mm}$. At a retention time in the kiln of about $45 \mathrm{~min}$, it is estimated that the samples were calcined at the maximal temperature for only about $10 \mathrm{~min}$. Table S3 shows the mean temperature at the zone of the highest temperatures of the kiln in relation to the set temperature. It is noted that apart from the experiment at the set temperature of $750{ }^{\circ} \mathrm{C}$, the mean temperature in the material bed measured in the high-temperature zone of the rotary kiln was always slightly lower than the set temperature $(25 \mathrm{~K}$ lower at $800-850{ }^{\circ} \mathrm{C}, 15 \mathrm{~K}$ lower at $900-1000{ }^{\circ} \mathrm{C}$ ).

The mass flow at the outlet was recorded. Steady-state conditions were reached after approximately $45 \mathrm{~min}$ and lasted for another 45 min until the feeding tube was empty. Periodical sampling was carried out during this period of steady-state and product composition was derived from this mixed sample. The sample was homogenized in an Eirich mixer for $20 \mathrm{~min}$ (R02, Eirich). A mixed sub-sample of $100 \mathrm{~g}$ was pulverized in a vibrating cup mill made of tungsten carbide (Pulverisette, Fritsch) and was used for subsequent analytics.

\section{Analysis}

\section{Total digestion and chemical analysis}

Digestion with aqua regia cannot completely solubilize sewage sludge ash (Krüger and Adam 2014). Therefore, the following and more potent digestion method based on perchloric and hydrofluoric acid was applied: $0.1 \mathrm{~g}$ of sample was mixed with $4 \mathrm{~mL} \mathrm{HNO}_{3}(65 \%), 1,5 \mathrm{~mL} \mathrm{HClO}_{4}(60 \%)$, and $0.5 \mathrm{~mL} \mathrm{HF} \mathrm{(48 \% )} \mathrm{and} \mathrm{was} \mathrm{digested} \mathrm{at} 240{ }^{\circ} \mathrm{C}$ for $15 \mathrm{~min}$ in a microwave (mikroPrepA, MLS GmbH, Leutkirch, Germany). After cooling, HF was complexed by addition of $2.5 \mathrm{~mL}$ cold saturated $\mathrm{H}_{3} \mathrm{BO}_{3}$ (ca. $5 \%$ ) and additional $10 \mathrm{~mL}$ de-ionized water and heating to $160{ }^{\circ} \mathrm{C}$ for $15 \mathrm{~min}$ (Krüger and Adam 2014). The solution was filtered (neoLab round filter paper type 388 ) and filled up to $50 \mathrm{~mL}$ with distilled water. The element concentrations of all digestion solutions were measured by ICP-OES (Thermo Fisher Scientific IRIS Intrepid II XSP in combination with Thermo Timberland IIS auto sampler). For ICP-OES measurements, a three-pointcalibration, including the blank, was used and measurements were carried out immediately after calibration. ICP-OES measurements were conducted in $10 \mathrm{~g} / \mathrm{L} \mathrm{LiNO}_{3}$ solution to suppress matrix effects. Trace elements were quantified by ICP-MS measurements (Thermo iCAP Q, Dreieich, Germany, kinetic energy discrimination mode (KED) with $\mathrm{He}$

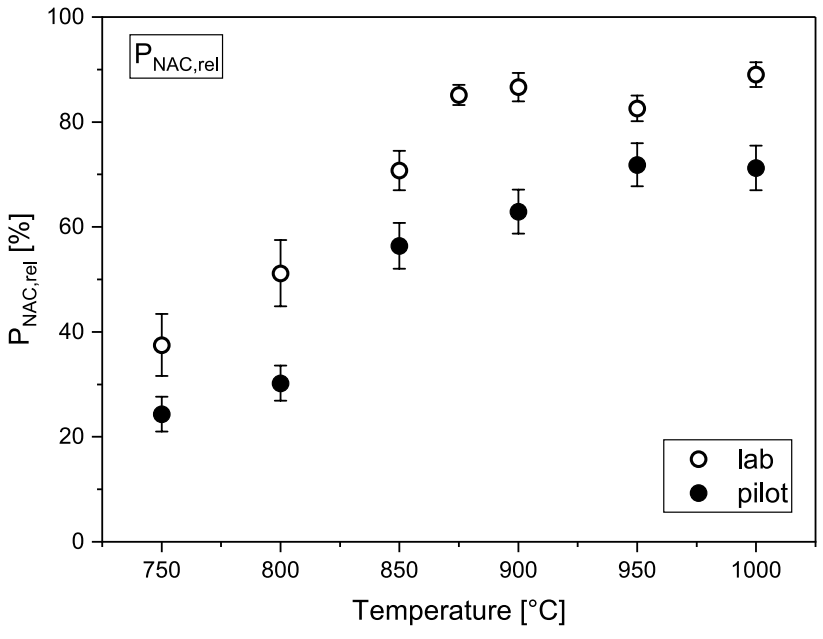

Fig. 2 Extractable phosphorus in neutral ammonium citrate $\left(\mathrm{P}_{\mathrm{NAC}, \text { rel }}\right)$ in samples calcined at different set temperatures in laboratory-scale and pilot-scale experiments

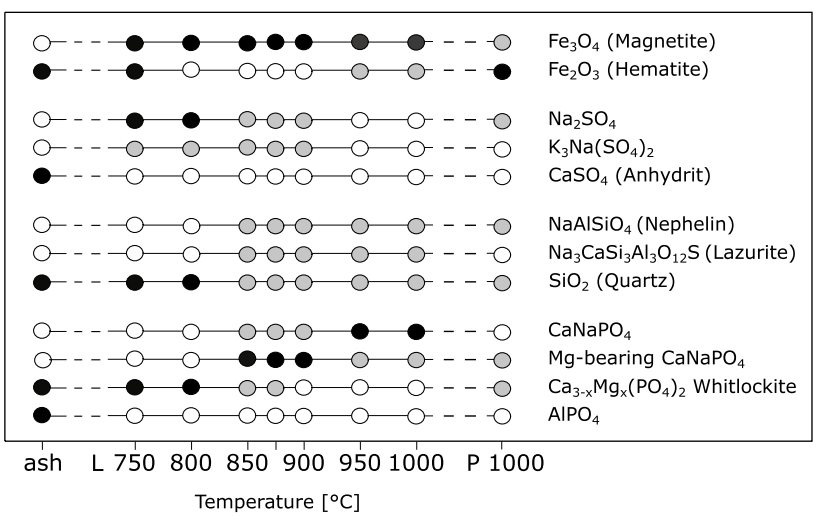

Fig. 3 Crystalline phases in the sewage sludge ash and thermochemical treated ash in laboratory-scale $\left(\mathrm{L} 750-1000{ }^{\circ} \mathrm{C}\right)$ and pilot-scale experiments $\left(\mathrm{P} 1000{ }^{\circ} \mathrm{C}\right)$. meaning of colours in circles: white "phase is absent", grey "minor amount" and black "high amount"

as collision gas). The digestion solution was diluted 1:100 and ${ }^{115}$ In was used as internal standard.

\section{Extractable phosphorus in neutral ammonium citrate}

Solubility of phosphorus in neutral ammonium citrate $\left(\mathrm{P}_{\mathrm{NAC}}\right)$ was determined according to EU (2003). The ratio of soluble phosphorus and total amount of phosphorus is defined as $\mathrm{P}_{\mathrm{NAC}, \text { rel }}$ in Fig. 2. $\mathrm{P}_{\mathrm{NAC}}$ concentrations of all digestion solutions were determined by ICP-OES.

\section{X-ray diffraction}

Powder X-ray diffraction analyses were done for fertilizer samples (Figs. 3,4) as well as for fertilizer samples after 
extraction in neutral ammonium citrate to verify reflexes disappearing due to extraction. Analyses were performed in Bragg-Brentano geometry over a $2 \theta$ range from $5^{\circ}$ to $80^{\circ}$, with a step size of $0.02^{\circ}$ (D8 Advance, Bruker AXS, Germany). The diffraction patterns were collected using $\mathrm{Cu}$ $\mathrm{K} \alpha 1 / \mathrm{K} \alpha 2(\lambda 1=1.54056 \AA / \lambda 2=1.54443 \AA)$ radiation. The diffraction patterns were recorded with a Lynxeye detector. Qualitative identification of the crystalline phases was performed using the MATCH! Software (Crystallin Impact 2018) in combination with the PDF2 database (ICDD 2003).

\section{Element mass balance of the pilot-scale experiment}

The element mass balance is shown in table S2. It was calculated on the element mass fraction (Table 1 and S1) and the weight of SSA $(5000 \mathrm{~g})$ and SS $(1000 \mathrm{~g})$ in the starting material and the thermochemical products (Table S2). The displayed value for the weight of thermochemical product (Table S2) is the sum of material collected in buckets, further material sampling during the trial and agglomerated materials at the rotary kiln walls which was removed after trial. The element removal given in Fig. 5 is calculated as $100 \%$ minus element mass fraction.

\section{Results and discussion}

\section{Pilot-scale observations}

Due to strongly convective gas transport provoked by hightemperature gradients, some air entered the rotary kiln via the partly open outlet. Some of the pyrolysis gases formed in the kiln were thus oxidized at the rearward part of the kiln. This was visually perceived by formation of a flame approximately at $1400 \mathrm{~mm}$ length where also the highest temperature was measured (Fig. S1).

At $750-800{ }^{\circ} \mathrm{C}$, only little adhesion of the material was observed. At temperatures above $850{ }^{\circ} \mathrm{C}$, material adhesion increased strongly and led to material build-up on the rotating tube. At higher temperatures, both inclination and rotational speed were therefore increased to compensate for otherwise slower material movement due to material adhesion. At $950-1000{ }^{\circ} \mathrm{C}$, a pronounced material ring formation at the wall of the reactor was observed. To assure a steady material flow, agglomerated material was manually removed periodically from the hot walls of the rotary tube with a steal bar. At a material feeding rate of $5.4 \mathrm{~kg} / \mathrm{h}$ and a total mass yield of approximately $80 \%$, a mass flow at the outlet of about $4.2 \mathrm{~kg} / \mathrm{h}$ was expected. The measured mass flows during the period of steady state, however, were in the range of $3.0 \mathrm{~kg} / \mathrm{h}$. Thus, some material accumulated in the tube and the ideal scenario of a period of steady state was not completely reached.
Material adhesion and ring formation are well-known phenomena of calcination processes. Techniques for caking removal for example in cement works range from abrupt temperature changes to the use of explosives. One potential solution might have been to operate the process below the sintering temperature range. This possibility, however, must be ruled out because sufficiently high temperatures are required to reach the desired solubility of phosphorus and heavy metal removal. Thus, from the current experiments, it appears that technical measures are necessary to remove caking from the kiln walls to assure long-term operation. However, the reactor walls are heated from the outside by an electric oven and have always a higher temperature than the calcined material in the present examination, whereas in a directly gas heated rotary kiln the opposite would be the case which may thus pose less problems.

\section{$\mathbf{P}_{\text {NAC }}$-solubility}

Figure 2 displays the $\mathrm{P}_{\mathrm{NAC}}$-solubility $\left(\mathrm{P}_{\mathrm{NAC} \text {,rel }}\right)$ of calcination products from laboratory-scale and pilot-scale experiments for the set temperatures between 750 and $1000{ }^{\circ} \mathrm{C}$. The data show a clear correlation of extractable phosphorus and treatment temperature at both laboratory- and pilot-scale. The strongest extractability increase was observed in the temperature range of $800-900{ }^{\circ} \mathrm{C}$. The fraction of phosphorus extractable in neutral ammonium citrate solution in raw ash is relatively low with approx. 20\% (Table 1). At rising treatment temperature, $\mathrm{P}_{\mathrm{NAC}}$-solubility increased strongly and for both laboratory-scale and pilot-scale samples a similar trend can be noted. However, the pilot-scale samples required higher temperatures to reach the maximum solubility which was $15 \%$ below the maximum solubility of samples from the laboratory-scale trials. For the laboratory-scale experiment, the maximum $\mathrm{P}_{\mathrm{NAC}}$-solubility of approx. $90 \%$ was already reached at temperatures $\geq 875^{\circ} \mathrm{C}$ whereas in pilotscale a maximum solubility of approx. $70 \%$ was reached at temperatures $\geq 950^{\circ} \mathrm{C}$.

Sodium sulphate has a melting point of $884{ }^{\circ} \mathrm{C}$ (Rowe et al. 1972). However, thermogravimetric experiments suggest that at reducing atmospheres sodium sulphate is decomposed already at approx. $600{ }^{\circ} \mathrm{C}$ (Vogel et al. 2016). Mass transport phenomena below the melting point are controlled by sintering. For sodium sulphate, it can be expected that sintering starts at approximately $500{ }^{\circ} \mathrm{C}$ (Okuyama 2006). The driver of transport mechanisms in homogenous powders is the reduction of the particle surface area. In heterogeneous mixtures, the gradient of the chemical potential is an additional driver. In both cases, diffusion results in a minimization of the Gibbs energy of the system. Transport mechanisms consist of viscous flow of glassy particles, surface diffusion, vacancy diffusion and interstitial diffusion in the crystalline lattice (Djohari et al. 2009). Frischat (1974) 
determined the self-diffusion coefficients of ${ }^{22} \mathrm{Na}$ and ${ }^{45} \mathrm{Ca}$ in the $\mathrm{Na}_{2} \mathrm{O}-\mathrm{CaO}-3 \mathrm{SiO}_{2}$ system. It was found that $\mathrm{Na}$ diffusion is several magnitudes higher in comparison to $\mathrm{Ca}$ due to its single charge and increases exponentially with temperature.

\section{Phase identification by X-ray diffraction analysis}

\section{Formation of silicates, sulphates and iron oxides}

The transformation of crystalline phases from sewage sludge ash to thermochemically treated samples in the laboratoryscale experiments $\left(750-1000{ }^{\circ} \mathrm{C}\right)$ is depicted in Fig. 3. Figure 4 compares the diffraction patterns of sewage sludge ash and thermochemically treated ashes from laboratory-scale and pilot-scale trials at $1000^{\circ} \mathrm{C}$.

Silicon and aluminium are main compounds of the amorphous phase (Luyckx et al. 2020; Mahieux et al. 2010) and bonded as quartz $\left(\mathrm{SiO}_{2}\right)$ and $\mathrm{AlPO}_{4}$ in the sewage sludge ash, respectively (Figs. 3,4). They react with the sodium additive sodium sulphate and form nepheline $\left(\mathrm{NaAlSiO}_{4}\right)$ and lazurite, a multi-component and sulphur-containing silicate phase with an assumed composition $\mathrm{Na}_{3} \mathrm{CaAl}_{3} \mathrm{Si}_{3} \mathrm{O}_{12} \mathrm{~S}$ that can occur in many isostructural types. Therefore, the exact chemical composition cannot be identified in this multicomponent phase mixture (Stemann et al. 2015). Lazurite was only identified in laboratory-scale experiments.

The presence or absence of the iron phases hematite $\left(\mathrm{Fe}_{2} \mathrm{O}_{3}\right)$ and magnetite $\left(\mathrm{Fe}_{3} \mathrm{O}_{4}\right)$, depends on the cooling regime and conditions. Magnetite is present in case of reducing conditions during cooling (laboratory experiment in covered crucibles) and hematite in case of oxidizing conditions (pilot-scale trials in rotary kiln with oxidative outlet zone).

\section{Formation of phosphate phases}

The crystalline phosphorus phases in the sewage sludge ash are $\mathrm{AlPO}_{4}$ and whitlockite type $\mathrm{Ca}_{3-\mathrm{x}}(\mathrm{Mg}, \mathrm{Fe})_{\mathrm{x}}\left(\mathrm{PO}_{4}\right)_{2}$, which can also incorporate further cations (e.g. $\mathrm{K}$ and $\mathrm{Na}$ ) (Morozov et al. 2000). However, the exact composition of the whitlockite type cannot be identified by XRD due to a nearly identical structure and thus similar diffractograms. $\mathrm{AlPO}_{4}$ is absent in all products after thermochemical treatment. The target of the thermochemical treatment with sodium sulphate is to transform all phosphorus phases to highly extractable $\mathrm{CaNaPO}_{4}$. In general, this phase reaction is incomplete below the melting point of the respective sulphate (Herzel et al. 2016). Thus, whitlockite and sodium sulphate are still present in samples up to $900{ }^{\circ} \mathrm{C}$ (Fig. 3). The reaction between sodium from sodium sulphate and whitlockite to $\mathrm{CaNaPO}_{4}$ starts at $850{ }^{\circ} \mathrm{C}$. The expected crystalline phase $\mathrm{CaNaPO}_{4}$ is only present in minor amounts in the temperature range between $850{ }^{\circ} \mathrm{C}$ and $900{ }^{\circ} \mathrm{C}$ and is dominant above $900{ }^{\circ} \mathrm{C}$ (Fig. 3). Instead, a Mg-bearing $\mathrm{CaNaPO}_{4}\left(\mathrm{Ca}_{13} \mathrm{Mg}_{5} \mathrm{Na}_{18}\left(\mathrm{PO}_{4}\right)_{18}\right)$ described by Alkemper and Fuess (1998) could be correlated to reflexes in the diffraction pattern and is the dominant phosphorus phase

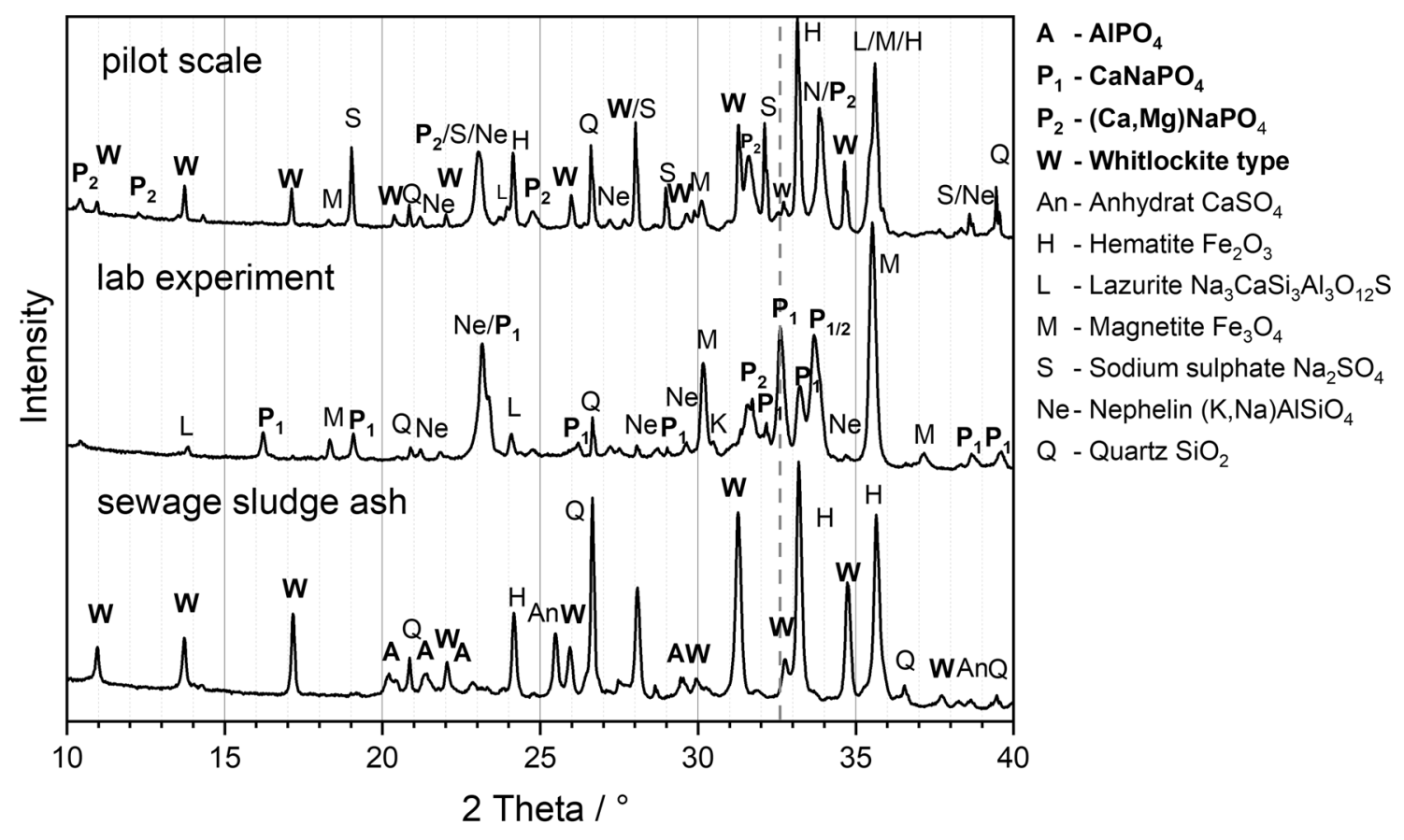

Fig. 4 Diffraction pattern of sewage sludge ash, the thermochemical treated ashes at $1000{ }^{\circ} \mathrm{C}$ in laboratory-scale and in pilot-scale experiments. The main reflex for $\mathrm{CaNaPO}_{4}\left(33.1^{\circ}\right)$ are marked as vertical dashed line 
in the temperature range from $850{ }^{\circ} \mathrm{C}$ to $900{ }^{\circ} \mathrm{C}$ (Fig. 3). Thus, a crystalline phase similar to $\mathrm{CaNaPO}_{4}$ was formed first where $\mathrm{Ca}$ is partly replaced by $\mathrm{Mg}$. This phase can be more generally expressed as $(\mathrm{Ca}, \mathrm{Mg}) \mathrm{NaPO}_{4}$. A peak shift to lower angles compared to the data-base entry of $\mathrm{Ca}_{13} \mathrm{Mg}_{5} \mathrm{Na}_{18}\left(\mathrm{PO}_{4}\right)_{18}$ indicates a lower portion of $\mathrm{Mg}$. The chemical composition found here can probably be estimated as $\mathrm{Ca}_{0.8} \mathrm{Mg}_{0.2} \mathrm{NaPO}_{4}$.

Phase reactions in pilot-scale behaved differently. Only Mg-bearing $\mathrm{CaNaPO}_{4}$ was identified as highly extractable phosphate phase (Fig. 3). However, whitlockite and sodium sulphate were still present in the samples from pilot-scale trials even at the highest operation temperatures (Figs. 3, 4). The lower $P_{\text {NAC }}$-solubility of samples from pilot-scale in comparison to laboratory-scale experiments can most likely be explained by the prevailing whitlockite type which is known to be poorly extractable (Kratz et al. 2019).

An analysis of the experimental differences of laboratoryand pilot-scale set-ups and comparison with results of thermochemical treatment with the additive sodium carbonate suggests two potential causes for an incomplete phosphorus phase reaction in the rotary kiln: (1) Exposure time at the set temperature in the rotary kiln was shorter (Fig. S1) and thus may have contributed to an apparent shift of the extractable phosphorus curve towards higher temperatures (Fig. 2). However, this does not explain the low value of $\mathrm{P}_{\mathrm{NAC} \text {,rel }}$ at $1000{ }^{\circ} \mathrm{C}$. (2) The incomplete phase reaction with phosphate phases is a result of incomplete decomposition of sodium sulphate due to insufficient reducing condition. Similar reaction was already observed in a demonstration-scale trial that achieved a $\mathrm{P}_{\mathrm{NAC}, \text { rel }}$ of $\sim 80 \%$ (Herzel et al. 2016). In contrast, complete phosphorus phase reaction between sewage sludge ash and sodium additive $\left(\mathrm{P}_{\mathrm{NAC}, \text { rel }}>90 \%\right)$ was achieved by using sodium carbonate instead of sodium sulphate as additive (Severin et al. 2014; Vogel et al. 2018). Thus, the use of sodium sulphate as additive is the topic of ongoing research to achieve higher extractable of phosphorus values in pilotscale experiments by precise adjustment of the reducing conditions required for the activation of sodium sulphate as an additive.

\section{Presence of $\mathrm{CaNaPO}_{4}$ and $\mathrm{Mg}$-bearing $\mathrm{CaNaPO}_{4}$}

The incomplete reactions during pilot-scale experiments at $1000{ }^{\circ} \mathrm{C}$ lead to similar phase composition compared to the $850^{\circ} \mathrm{C}$ trial in the laboratory-scale experiment (Fig. 3). Both samples represent an incomplete phase reaction and contain $\mathrm{Mg}$-bearing $\mathrm{CaNaPO}_{4}$ as dominant high extractable phosphorus phase. This indicates that $\mathrm{Mg}$-bearing $\mathrm{CaNaPO}_{4}$ might be an intermediate compound between $\mathrm{Mg}$-bearing Whitlockite $\mathrm{Ca}_{3-\mathrm{x}}(\mathrm{Mg}, \mathrm{Fe})_{\mathrm{x}}\left(\mathrm{PO}_{4}\right)_{2}$ and $\mathrm{CaNaPO}_{4}$. Current temperature study between $750{ }^{\circ} \mathrm{C}$ and $1000{ }^{\circ} \mathrm{C}$ in laboratory-scale illustrates that $\mathrm{Ca}_{1-\mathrm{x}} \mathrm{Mg}_{\mathrm{x}} \mathrm{NaPO}_{4}$ is an intermediate phase and thus confirms the previous postulation by Steckenmesser et al. (2019).

Nevertheless, the presence of $\mathrm{Mg}$-bearing $\mathrm{CaNaPO}_{4}$ or $\mathrm{CaNaPO}_{4}$ has no influence on the extraction in neutral ammonium citrate. The constant high values of $\mathrm{P}_{\mathrm{NAC}, \text { rel }}$ above $850{ }^{\circ} \mathrm{C}$ confirmed that $\mathrm{Mg}$-bearing $\mathrm{CaNaPO}_{4}$ is also completely extractable in neutral ammonium citrate like $\mathrm{CaNaPO}_{4}$ (Herzel et al. 2016; Kratz et al. 2019).

\section{Element mass balance and element removal of the pilot-scale experiment}

Element mass balance given in Table $\mathrm{S} 2$ was calculated based on element mass fractions in the sewage sludge ash, sewage sludge and thermochemical products and their amounts. It was determined for all evaluated elements including matrix elements. Thus, elements could be identified which remain in solid phase or are removed via gas phase (As, $\mathrm{Cd}, \mathrm{Mo}, \mathrm{Pb}, \mathrm{Sb}, \mathrm{Sn}$ ). High variation in element recovery (75-120\%) for matrix elements $\mathrm{Al}, \mathrm{Fe}, \mathrm{P}$ and $\mathrm{Si}$ are apparently influenced by uncertainties during chemical analysis (Table S2). Satisfying narrow deviations are calculated for $\mathrm{Ca}, \mathrm{Mg}, \mathrm{Cu}, \mathrm{Mn}$, and $\mathrm{Ti}(90-110 \%)$. Zinc is probably removed in minor fractions via gas phase (Herzel et al. 2016) with a maximal removal of $15 \pm 2 \%$ (Table S2).

Figure 5 displays experimental $\mathrm{As}, \mathrm{Cd}$ and $\mathrm{Pb}$ removal. It is shown that removal of $\mathrm{As}, \mathrm{Cd}$ and $\mathrm{Pb}$ started from $800{ }^{\circ} \mathrm{C}$ and increased with temperature. The maximum removal was $31 \pm 10 \%$ for As, $54 \pm 3 \%$ for $\mathrm{Cd}$ and $32 \pm 5 \%$ for $\mathrm{Pb}$ at $1000{ }^{\circ} \mathrm{C}$ (Fig. 5). These data confirmed early findings

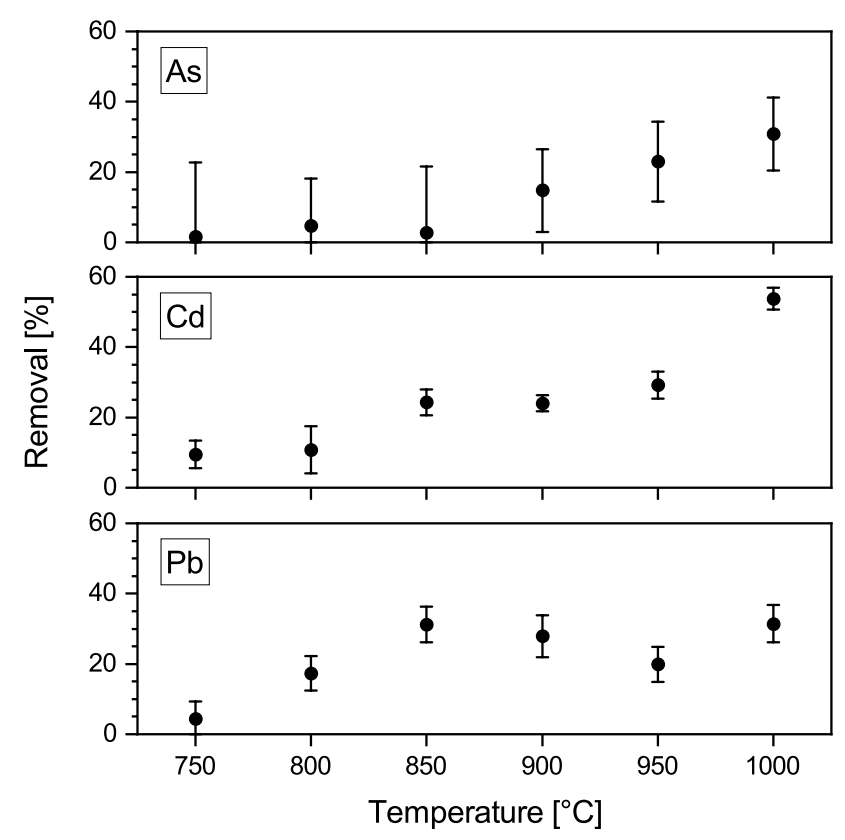

Fig. 5 Element removal of $\mathrm{As}, \mathrm{Cd}$ and $\mathrm{Pb}$ of pilot-scale experiments. Calculated by $100 \%$ —element mass balance (Table S2) 
by Herzel et al. (2016) and Vogel et al. (2016). However, investigations with the additive sodium carbonate showed even higher removal of $\mathrm{Pb}$ up to $90 \%$ (Adam 2020). The thermochemical treatment of sewage sludge ash is furthermore suitable to remove also mercury and thallium (Herzel et al. 2016; Vogel et al. 2016). In addition, removal for Sb, Mo and Sn was observed (Table S2). These elements are not in the focus for removal investigation as $\mathrm{Sb}$, Mo and $\mathrm{Sn}$ are not considered as toxic elements for fertilizer production (EU 2003).

The formations of different gaseous phases are responsible for removal of $\mathrm{As}, \mathrm{Cd}$ and $\mathrm{Pb}$. The mechanism for arsenic evaporation under reducing conditions is most likely the formation of elementary arsenic or gaseous species of $\mathrm{As}_{2} \mathrm{O}_{3}$ ( $\mathrm{Lu}$ and Yin 2016) and for Cd the formation of elementary $\mathrm{Cd}$ (Vogel et al. 2016). A likely mechanism for the removal of $\mathrm{Pb}$ may be the formation of elemental $\mathrm{Pb}$ and $\mathrm{PbS}$ (Struis et al. 2009). Due to the reducing atmosphere and the presence of high $\mathrm{S}$ mass fractions, considerable fractions of $\mathrm{PbS}$ may have formed, which already shows appreciable evaporation rates at $900{ }^{\circ} \mathrm{C}$ (El-Rahaiby and Rao 1982).

At higher reaction temperatures, element removal increased further for these elements. At rising temperature, both kinetics of heavy metal reducing reactions, as well as vapour pressures of heavy metal species increase. Both fundamentals thus explain increased $\mathrm{As}, \mathrm{Cd}$ and $\mathrm{Pb}$ removal at higher temperatures. One experimental constraint limiting element removal may have been partly oxidizing conditions in the rearward part of the rotary kiln. Thereby some of the heavy metals may have been re-oxidized resulting in the formation of dust particles. Together with colder surface temperatures towards the end of the kiln, re-deposition of heavy metals on the solid product may have occurred. In general, counter-current gas flow is expected to more efficiently remove heavy metals than the co-current regime chosen for the present experiments.

Removal rates in laboratory-scale experiments at $1000{ }^{\circ} \mathrm{C}$ amounted to $21 \pm 8 \%$ for $\mathrm{As} ; 30 \pm 5 \%$ for $\mathrm{Cd}$ and $17 \pm 4 \%$ for $\mathrm{Pb}$ (data not shown), and thus were significantly lower than in pilot-scale. This is explainable by the stationary conditions in the crucible experiments resulting in gaseous and mass transfer limitations for reactions between heavy metals and reducing atmosphere. Furthermore, the low gas flow in the covered crucible limits the removal of gaseous metal species.

In the present investigation, the gas flow in the rotary kiln was approximately $0.2 \mathrm{Nm}^{3} / \mathrm{kg}$ ash in addition to approximately $0.1 \mathrm{Nm}^{3} / \mathrm{kg}$ ash of pyrolysis gas formed during the reaction and thus was close to a gas flow of $0.4 \mathrm{Nm}^{3} / \mathrm{kg}$ ash predicted for a full-scale integrated incineration and post-treatment facility (Herzel et al. 2016). The gas flow is thought to constantly reduce the partial pressure of heavy metals in the kiln and may thus control the evaporation rate of metals. Yet, in demonstration-scale in a directly fired kiln at $950{ }^{\circ} \mathrm{C}$ even higher removal rates of $67 \%$ for As, $40 \%$ for $\mathrm{Pb}$ and $80 \%$ for $\mathrm{Cd}$ were reached (Herzel et al. 2016). Altogether, heavy metal removal at the chosen reaction conditions remains incomplete. Likely, a higher carbon to ash ratio in addition to higher temperatures would be needed to further increase heavy metal removal.

\section{Conclusion}

Calcination of sewage sludge ash with sodium sulphate under reducing conditions removes heavy metals and forms a plant available product suitable for phosphorus fertilizer production. Process upscaling was explored at varying temperatures by comparison of continuous experiments at $5 \mathrm{~kg} / \mathrm{h}$ in a rotary kiln with laboratory-scale crucible experiments of $16 \mathrm{~g}$. The heavy metal removal ( $\mathrm{As}, \mathrm{Cd}, \mathrm{Pb}$ ) was significantly higher in pilot-scale compared to laboratory-scale experiments. This can be explained by more effective gas transport processes in the rotary kiln compared to the experimental set-up of covered crucible trials.

It was shown that treatment at a temperature of $875^{\circ} \mathrm{C}$ for 30 min was sufficient to achieve maximal extractable phosphorus in the laboratory-scale experiments. In the pilot-scale experiment, a higher temperature of $950{ }^{\circ} \mathrm{C}$ was required to achieve maximal extractable phosphorus. This might be due to retention times that were below $30 \mathrm{~min}$ at the set operation temperature and thus not directly comparable to the crucible trials. However, the maximum fraction of extractable phosphorus was generally lower for the pilot-scale compared to laboratory-scale experiments even at the maximum temperature of $1000{ }^{\circ} \mathrm{C}$. This was a result of incomplete reaction of poorly soluble phosphate phase whitlockite with sodium sulphate due to insufficient redox conditions. In the covered crucibles, the reducing atmosphere was provided and thus the decomposition of sodium sulphate and subsequent reaction with the phosphate phases was complete. For large-scale rotary kiln operation, this could be a crucial aspect. Reducing conditions have to be adjusted properly to achieve complete reaction and formation of plant available $\mathrm{CaNaPO}_{4}$. An alternative is utilization of sodium carbonate instead of sodium sulphate as it already decomposes at low temperature and also under oxidizing conditions. This was already proven in laboratory-scale and pilot-scale experiments.

The fraction of extractable phosphorus is directly correlated with the phosphorus phase composition. High extractability of thermochemical products is related to the formation of the calcium sodium phosphate phases $\mathrm{CaNaPO}_{4}$ and $\mathrm{Mg}$ bearing $\mathrm{CaNaPO}_{4}$, a phase seldomly described before. The laboratory-scale experiments implicate that the $\mathrm{Mg}$-bearing $\mathrm{CaNaPO}_{4}$ has a comparable extractability as $\mathrm{CaNaPO}_{4}$ and might be an intermediate phase between whitlockite and 
$\mathrm{CaNaPO}_{4}$. Lower levels of solubility of phosphorus were clearly related to unreacted whitlockite.

Supplementary Information The online version of this article (https:// doi.org/10.1007/s13762-021-03252-y) contains supplementary material, which is available to authorized users.

Acknowledgement A majority of the experimental work was carried out in the course of the P-REX project, funded by the European Commission within the 7th EU Framework Programme, Grant Agreement no. 308645 and the framework of the project ASHES, funded by the German Federal Ministry of Education and Research (BMBF, grand number 031A288). The authors would like to thank Marcus Bork for his help with the rotary kiln experiments.

Funding Open Access funding enabled and organized by Projekt DEAL.

Open Access This article is licensed under a Creative Commons Attribution 4.0 International License, which permits use, sharing, adaptation, distribution and reproduction in any medium or format, as long as you give appropriate credit to the original author(s) and the source, provide a link to the Creative Commons licence, and indicate if changes were made. The images or other third party material in this article are included in the article's Creative Commons licence, unless indicated otherwise in a credit line to the material. If material is not included in the article's Creative Commons licence and your intended use is not permitted by statutory regulation or exceeds the permitted use, you will need to obtain permission directly from the copyright holder. To view a copy of this licence, visit http://creativecommons.org/licenses/by/4.0/.

\section{References}

AbfKlärV (2017) Verordnung über die Verwertung von Klärschlamm, Klärschlammgemisch und Klärschlammkompost (Klärschlammverordnung - AbfKlärV) 27.09.2017. Germany

Adam C (2020) R-Rhenania: Modifizieres Rhenania Phosphat aus Klärschlammasche für Bayern. Presentation at the 6. Kongress Phosphor - ein kritischer Rohstoff mit Zukunft, Stuttgart, 25-26/11/2020. Plattform P-Rueck.

Alkemper J, Fuess H (1998) The crystal structures of NaMgPO4, $\mathrm{Na} 2 \mathrm{CaMg}(\mathrm{PO} 4) 2$ and $\mathrm{Na} 18 \mathrm{Ca} 13 \mathrm{Mg} 5(\mathrm{PO} 4) 18$ : new examples for glaserite related structures Zeitschrift für Kristallographie. Cryst Mater 213:282-287. https://doi.org/10.1524/zkri.1998.213.5.282

Djohari H, Martínez-Herrera JI, Derby JJ (2009) Transport mechanisms and densification during sintering: I. Viscous flow versus vacancy diffusion. Chem Eng Sci 64:3799-3809. https://doi.org/ 10.1016/j.ces.2009.05.018

EC (2013) Consultative communication on the sustainable use of phosphorus. http://ec.europa.eu/environment/consultations/pdf/phosp horus/EN.pdf. Accessed 2013

EC (2014) 20 critical raw materials - major challenge for EU industry. http://europa.eu/rapid/press-release_IP-14-599_en.htm. Accessed 13 May 2020

EC (2017) Communication from the European Commission on the 2017 list of critical raw materials for the EU. http://eur-lex.europa. eu/legal-content/EN/TXT/?uri=COM:2017:490:FIN. Accessed 2017

Eleventh European Powder Diffraction Conference. In. De Gruyter, Berlin, Boston, pp 459-464. doi:https://doi.org/https://doi.org/10. 1524/9783486992588-072
El-Rahaiby SK, Rao YK (1982) Kinetics of vaporization of lead sulfide. Metall Trans B 13:633-641. https://doi.org/10.1007/ BF02650021

DIN EN 15957:2011 Düngemittel - extraktion des in neutralem Ammoniumcitrat löslichen Phosphors

EU, (2003) Regulation (EC) No 2003/2003 of the European parliament and of the council of 13 October 2003 relating to fertilizers. Brussel, Belgium

Frischat GH (1975) Comparison of atom mobility in crystalline and glassy oxides. In: Cooper AR, Heuer AH (eds) Mass transport phenomena in ceramics. Springer, Boston, MA

Gilbert N (2009) Environment: the disappearing nutrient. Nature 461:716-718. https://doi.org/10.1038/461716a

Gunawardane RP, Glasser FP (1979) Reaction of chlorapatite, $\mathrm{Ca} 5(\mathrm{PO} 4) 3(\mathrm{Cl}, \mathrm{F})$ with sodium carbonate and silica. J Mate Sci 14:2797-2810

Herzel H, Krüger O, Hermann L, Adam C (2016) Sewage sludge ash A promising secondary phosphorus source for fertilizer production. Sci Total Environ 542:1136-1143. https://doi.org/10.1016/j. scitotenv.2015.08.059

Herzel H, Grevel K-D, Emmerling F, Dachs E, Benisek A, Adam C, Majzlan J (2020) Thermodynamic properties of calcium alkali phosphates $\mathrm{Ca}(\mathrm{Na}, \mathrm{K}) \mathrm{PO} 4$. J Mater Sci 55:8477-8490. https:// doi.org/10.1007/s10853-020-04615-5

ICDD (2003) International Centre for Diffraction Data PDF-2 (Database). Newtown Square, PA, USA

Crystallin Impact (2018) Match! version 3.6 [Computer software]. Crystal Impact GbR, Bonn

Kratz S, Vogel C, Adam C (2019) Agronomic performance of $P$ recycling fertilizers and methods to predict it: a review. Nutr Cycl Agroecosyst 115:1-39. https://doi.org/10.1007/ s10705-019-10010-7

Krüger O, Adam C (2014) Monitoring von Klärschlammmonoverbrennungsaschen hinsichtlich ihrer Zusammensetzung zur Ermittlung ihrer Rohstoffrückgewinnungspotentiale und zur Erstellung von Referenzmaterial für die Überwachungsanalytik, Forschungskennzahl (UFO-PLAN) 371133 321. Umweltbundesamt

Krüger O, Grabner A, Adam C (2014) Complete survey of German sewage sludge ash. Environ Sci Technol 48:11811-11818. https:// doi.org/10.1021/es502766x

Lu W-h, Yin Z-1 (2016) Study on thermal decomposition and arsenic removal of a silver bearing copper ore. Int J Miner Process 153:1-7. https://doi.org/10.1016/j.minpro.2016.05.016

Luyckx L, Geerts S, Van Caneghem J (2020) Closing the phosphorus cycle: Multi-criteria techno-economic optimization of phosphorus extraction from wastewater treatment sludge ash. Sci Total Environ 713:135543. https://doi.org/10.1016/j.scitotenv.2019.135543

Mahieux PY, Aubert JE, Cyr M, Coutand M, Husson B (2010) Quantitative mineralogical composition of complex mineral wastes Contribution of the Rietveld method. Waste Manag 30:378-388. https://doi.org/10.1016/j.wasman.2009.10.023

Morozov VA, Belik AA, Kotov RN, Presnyakov IA, Khasanov SS, Lazoryak BI (2000) Crystal structures of double calcium and alkali metal phosphates Ca10M(PO4)7(M = Li, Na, K). Crystallogr Rep 45:13-20. https://doi.org/10.1134/1.171129

Nanzer S, Oberson A, Huthwelker T, Eggenberger U, Frossard E (2014) The molecular environment of phosphorus in sewage sludge ash: implications for bioavailability. J Environ Qual 43:1050-1060. https://doi.org/10.2134/jeq2013.05.0202

Okuyama K (2006) Sintering. In: Masuda H, Higashitani K, Yoshida H (eds) Powder technology handbook, vol 3. CRC Press, Boca Raton

Orlov NK, Evdokimov PV, Milkin PA, Garshev AV, Putlayev VI, Grebenev VV, Günster J (2019) Phase equilibria in CaNaPO4$\mathrm{CaKPO} 4$ system and their influence on formation of bioceramics based on mixed Ca-K-Na phosphates. J Eur Ceram Soc 39:5410 5422. https://doi.org/10.1016/j.jeurceramsoc.2019.07.044 
Peplinski B, Adam C, Michaelis M, Kley G, Emmerling F, Simon FG (2009) Reaction sequences in the thermo-chemical treatment of sewage sludge ashes revealed by X-ray powder diffraction - A contribution to the European project SUSAN

Rowe JJ, Morey GW, Zen CS (1972) The quinary reciprocal salt system $\mathrm{Na}, \mathrm{K}, \mathrm{Mg}, \mathrm{Ca} / \mathrm{Cl}, \mathrm{SO} 4$ - a review of the literature with new data. Geological Survey Professional Paper

Severin M, Breuer J, Rex M, Stemann J, Adam C, Van den Weghe H, Kücke M (2014) Phosphate fertiliser value of heat treated sewage sludge ash. Plant Soil Environ 60:555-561

Steckenmesser D, Vogel C, Steffens D (2019) Medium-scale plant experiment of sewage sludge-based phosphorus fertilizers from large-scale thermal processing. Commun Soil Sci Plant Anal 50:2469-2481. https://doi.org/10.1080/00103624.2019.1667373

Stemann J, Peplinski B, Adam C (2015) Thermochemical treatment of sewage sludge ash with sodium salt additives for phosphorus fertilizer production - Analysis of underlying chemical reactions. Waste Management 45:385-390. https://doi.org/10.1016/j.wasman.2015.07.029

Struis RPWJ, Nachtegaal M, Mattenberger H, Ludwig C (2009) The fate of lead in MSWI-Fly ash during heat treatment: an x-ray absorption spectroscopy study. Adv Eng Mater 11:507-512. https://doi.org/10.1002/adem.200800324

van Dijk KC, Lesschen JP, Oenema O (2016) Phosphorus flows and balances of the European Union Member States. Sci Total Environ 542:1078-1093. https://doi.org/10.1016/j.scitotenv.2015.08.048
Vogel C, Krüger O, Adam C (2016) Thermochemical treatment of sewage sludge ash with sodium additives under reducing conditions analyzed by thermogravimetry. J Therm Anal Calorim 123:10451051. https://doi.org/10.1007/s10973-015-5016-z

Vogel C, Rivard C, Wilken V, Muskolus A, Adam C (2018) Performance of secondary P-fertilizers in pot experiments analyzed by phosphorus X-ray absorption near-edge structure (XANES) spectroscopy. Ambio 47:62-72. https://doi.org/10.1007/ s13280-017-0973-z

VVEA (2016) Verordnung über die Vermeidung und die Entsorgung von Abfällen (VVEA). Switzerland

Werner W (1967) Die Rhenania-Dünger. Verlag M. u. H. Schaper, Hannover, Germany, Monographie über Herstellung, Eigenschaften und Wirkung der Rhenania-Dünger

Widmer R, Gfeller F, Armbruster T (2015) Structural and crystal chemical investigation of intermediate phases in the system Ca2SiO4Ca3(PO4)2-CaNaPO4. J Am Ceram Soc 98:3956-3965. https:// doi.org/10.1111/jace. 13850

Zimmermann M Die neuen gesetzlichen Regelungen für mineralische Recyclingdünger. In: BAFU B (ed) Phosphor-Tagung, Bern, Switzerland, 30. August 20172017 